\title{
The Immigration Act and the 'Right to Rent': exploring governing tensions within and beyond the state (Policy Commentary)
}

\author{
Joe Crawford, * Sharon Leahy and Kim McKee \\ University of St Andrews
}

\begin{abstract}
Using Scotland as a case study, this paper will review the implications of the 'right to rent' section of the Immigration Act 2016 for matters of devolved legal competence, such as housing. Outlining the main criticisms from a wide range of agencies and institutions, this paper will go on to argue that these measures cannot be understood in isolation from the wider activities of a neo-liberal government embroiled in the pursuit of border enforcement at one end, while utilising non-state actors in petty sovereign roles to enforce and reify the border on the other. In doing so, we highlight governing tensions within and beyond the state, including between governments at the UK and Scotland level, between landlords and the state, and between landlords and their tenants. In doing so, we illuminate the ways in which the Act is augmenting the State's role by making border agents of us all.
\end{abstract}

Keywords: housing policy, immigration, private rented sector, devolution, governance.

\section{Introduction}

The proposals of the UK Immigration Act 2016 have been the focus of widespread criticism from, among others: devolved governments, opposition parties in Westminster, human rights groups, charities and welfare service providers. Taking as its object of interest the 'right to rent' section of the Act, this paper will, using Scotland as a case study, focus on the impact of such legislation on matters which are of devolved legal competence. To be clear, this Act applies across the UK despite housing and criminal law being devolved matters in Scotland.

This paper will outline the broad directives of the Act before highlighting some aspects relevant to the proposed changes prescribed by the 'right to rent' section, including the historical significance of statutory housing rights in Scotland, and an assessment of the Act's impact on the devolved competencies of housing and criminal law. It will then give a brief summary of some of the main objections to the Act before providing a theoretically informed exploration of some of its wider social and political 
p. 115. The Immigration Act and the 'Right to Rent': exploring governing tensions within and beyond the state (Policy Commentary)

implications for both the landlords and tenants involved, and Scottish devolved jurisprudence. The final section will outline potential areas for future research.

Before turning to the specifics of the Act, it is however important to consider the broader context of housing and immigration, which shapes and underpins this legislation. A pertinent example of the political rhetoric being mobilised was the recent comment made by former UK Government Minister Liam Fox, who asserted in a speech given as part of the 'Vote Leave' EU referendum campaign, that further "uncontrolled migration" will make it "harder" for young people to get a home of their own (quoted in BBC News, 2016: no page number). The reality behind this rhetoric is however much more complex, for "different types of migrants, with different rights, opportunities and resources are likely to have very different experiences in and impacts on the UK housing system" (Vargas-Silva, 2015: 2). Despite political parties on the Right seeking to 'blame' migrants for adding pressure to social housing waiting lists, and pushing up private sector rents and house prices (see for example, Telegraph, 2013; Daily Mail, 2016) the majority find themselves navigating the private rented sector under very difficult circumstances, and with increasingly little support from the government either in terms of help with their rent, or in their ability to access social housing (Manning et al., 2014; Vargas-Silva, 2015). Crucially, recent migrant groups are likely to have quite different experiences to previous cohorts (Vargas-Silva, 2015; Robinson, 2010, 2006). They are far-more likely to be found in the private rented sector, making the implications of the 'right to rent' legislation highly significant for this group and worthy of further critical investigation.

\section{Introduction to the Immigration Act 2016}

The background to the Immigration Act is controversial and highly contestable. From the perspective of the UK Conservative government, illegal immigration is an 'ongoing problem', which it seeks to further address through the Immigration Act 2016. For opposition parties, the devolved governments of Scotland, Wales and Northern Ireland, as a well as church groups, charities and other stakeholder agencies, the problem of 'illegal immigration' is grossly exaggerated. What is jointly acknowledged, however, is that there is at present a humanitarian crisis involving the mass migration of refugees and asylum seekers fleeing to Europe (see for example, Scottish Refugee Council, 2015a; Abbasi et al., 2015; Albahari, 2015).

The Home Office (2016) justifies the necessity of introducing the Act by stating that the previous Immigration Act 2014, although fairly comprehensive, does not go far enough in reducing 'illegal immigration' in the UK. The new 'powers', which the 2016 Act proposes are, the Home Office claims, designed to actively deny 'illegal immigrants' access to employment markets and a variety of 'services' within the UK, including housing, banking and public-facing public sector employment roles. The overarching aims of the 2016 Act are, according to the Home Office (2016), to make the UK a less attractive place for illegal immigrants and those who seek to exploit them. These aims are linked to a wider strategy, which involves the UK government re-negotiating the terms of EU-wide benefit entitlements for immigrants who would have otherwise had recourse to public funds under existing legislation.

Section 1 of the Act is concerned with the labour market and illegal labour abuse and enforcement. The Government's consultation ended on 7 December 2015 resulting in the publication of the Government's guidance (UK Visas and Immigration \& Home Office, 2015a) on Part 1 of the Act, which deals with the exploitation of the labour market by: making it a criminal offence to work without documentation, seizing 
p. 116. The Immigration Act and the 'Right to Rent': exploring governing tensions within and beyond the state (Policy Commentary)

illegal workers' earnings as the proceeds of crime, making it easier to prosecute employers, and making sanctions tougher.

Part 2 deals with 'access to services' including residential tenancies, driving licences and bank accounts. According to the Government (UK Visas and Immigration and Home Office, 2015b), Part 2 of the Act, building on the right to rent provisions first outlined for England in the 2014 Immigration Act, will make it more difficult to live and work in the UK without documentation by: making it easier for private landlords to evict migrant tenants who are not legally in the country, and by creating a new criminal offence for dishonest landlords and agents who exploit migrants and repeatedly fail to carry out right to rent checks. The Act also ensures that those unlawfully present in the UK are unable to drive. It also requires banks and building societies to take action against existing account holders who are unlawfully residing in the UK, thus placing an obligation on banks and building societies to carry out periodic checks of the immigration status of existing current account holders.

One of the other areas of significant change is contained within Part 4, which makes it easier to remove those who have no right to remain within the UK. The Act proposes to force those who wish to lodge an appeal against a deportation decision, to do so from the country from which they entered the UK. This will result in those wishing to appeal being removed from the UK before any appeal process is permitted to begin. Part 7 ensures that all customer facing, public sector workers will speak fluent English. The proposal is that a 'special helpline' be set up so that members of the public can report public sector workers whose English language skills do not meet the required standard.

These proposed new regulations present a multitude of state strategies to make the life of migrants, both those who are legal and illegal in the eyes of the State, more contentious and precarious, bestowing a slew of regulatory mechanisms that migrants must overcome to acquire a place to stay, banking services, driving rights, and public employment. Furthermore, it shifts the responsibility of scrutiny and adherence onto landlords, bank employees and public sector managers in efforts to discharge policing and accountability to lay citizens. The devolution of autonomy and responsibility downwards from the state to local actors, is not new (McKee, 2011, 2015), however this new series of regulations makes the entire citizenry duty bound to border protection. This liability is further entrenched by threats of extensive fines and custodial sentences for (private) landlords who fail to monitor and comply. Moreover, it affords the general populace an opportunity to report on and denunciate those who they deem to be lacking in adequate English language skills. This is making territorial agents and border detectives of us all. As the remainder of this paper will explore this reconfiguration of state-citizen relations is complex and multi-faceted: seeking to change the relationship between the tenant and their landlord, as well as between landlords and the state.

\section{History, autonomy and devolution: The problem for Scotland}

The 'right to rent' section of the Immigration Act 2016 is problematic for Scotland for three reasons. Firstly, it imposes the necessity for landlords to summarily evict tenants who have no 'right to rent' under the proposed terms of the Act, a provision which landlords have been precluded from doing in Scotland since 1555. Secondly, it affects an area of legislation (housing), which is devolved to the Scottish Parliament under the 1998 Scotland Act. This legislation devolved a range of major public policy areas, including housing, from the UK to the Scottish Government (for more detailed 
p. 117. The Immigration Act and the 'Right to Rent': exploring governing tensions within and beyond the state (Policy Commentary)

discussion see McKee et al, 2016). Thirdly, it exposes a significant policy gap in attitudes towards immigration across the different constituent parts of the UK.

The 'right to rent' scheme, a fundamental component of the current Immigration Act, requires that landlords check immigration documents and refuse to rent to anyone disqualified from doing so by their immigration status. The scheme prescribes that, should they discover their tenant has no 'right to rent', landlords evict after 28 days' notice without the normal statutory safeguards. This includes families with children. Landlords also face a fine or up to five years imprisonment if they rent to a person who does not have the 'right to rent'. The Immigration Act directly contradicts current Scottish legislation, such as the Housing (Scotland) Act 1987 (HMSO, 1987) as Amended, which not only protects tenants against summary eviction, but also extends their right to remain in the property until decree for eviction has been sought and enacted by Sheriff Officers.

Specifically, section 40 of the 2016 Act states:

(6) The notice is to be treated as a notice to quit in a case where a notice to quit would otherwise be required to bring the residential tenancy agreement to an end.

(7) The notice is enforceable as if it were an order of the High Court.

This removes the current requirement for landlords to obtain decree through raising a summary cause action in the Sheriff Court, a significant change that allows for a practice, which has not existed in Scotland, for well over 500 years (Stalker, 2007). It is also important to note that the new legislation allows for a landlord to have a conditional tenancy with the tenant. The tenancy can be time-limited to the legal period the tenant is allowed to remain in the UK, if the tenants' documentation, right to remain or permission to stay within the UK is due to expire, or is revoked, then the tenant will lose their tenancy rights and no process is in place to recoup lost rent or deposits. It is then in direct tension with the principles of the Private Housing (Tenancies) (Scotland) Act 2016, which seeks to give tenants in the private rented sector greater security of tenure by ending the 'no fault' ground for possession (McKee et al., 2016; HMSO, 2016). This means they can no longer be asked to leave the property by the landlord, simply because they have reached the end date of their tenancy. In addition, the right to rent proposals contradict Section 3 of the Tenancy Deposit Schemes (Scotland) Regulations 2011 (HMSO, 2011) which arose from the section 122 of the Housing (Scotland) Act 2006 (HMSO, 2006), and which protects tenancy deposits for tenants.

Housing legislation and tenant's rights within Scottish law have a rather long history with the first statutory regulation of evictions arising from the Housing Act of 1555 . This Act was passed "to rid the country of the violence which was a usual accompaniment to the older removings ... on verbal warnings only" (quoted in Stalker, 2007: 4). This was where the current 40 day notice period originated, as the 1555 Act stated that a landlord had to issue such, which if the tenant failed to heed, could result in the landlord seeking a decree in the Sheriff Court. Once the decree had been granted, the "landlord had then to apply directly to the Local Sheriff for a warrant of ejection" (Stalker, 2007: 4). Not only does the Immigration Act propose to significantly erode a comprehensive package of rights for certain tenants, which has not only been a statutory provision for almost 600 years, it threatens to affect an issue that has been of devolved competence for some 15 years. The Act could also potentially impact on Section 251 (c) of the Children (Scotland) Act 1995 (HMSO, 1995), which prescribes that when an adult is unable to provide accommodation for a child, then the local authority shall have a statutory obligation to do so. Up until now, this has generally 
p. 118. The Immigration Act and the 'Right to Rent': exploring governing tensions within and beyond the state (Policy Commentary)

meant accommodating the entire family, as social work departments are extremely reluctant to take children into their care simply on the grounds of homelessness. The Immigration Act could see more children taken into care as a result of their parents or guardians being unable to provide accommodation.

This brings us to the issue of the Scotland Act and the right of the Scottish Parliament to be consulted over areas of devolved competency. Given that housing is one such devolved competence, any extension to Scotland of the Immigration Act, including its prescriptions under the 'right to rent', are highly problematic. Indeed the Law Society of Scotland (2015: no page number) have expressed concerns around its practical implementation given that, "some of the proposals in this Act engage a range of devolved issues, and that it would be appropriate to initiate consultation with a view to seeking the legislative consent of the Scottish Parliament". A key tension here is that housing is a devolved competence but immigration law is not. As this is part of an Immigration Act, the knock on legislative changes to devolved issues are in muddy waters. The Law Society of Scotland has stated that because of this impact on devolved matters there should be a Legislative Consent Motion raised on the Act.

Clearly, this tension illuminates a significant disjuncture in government attitudes towards immigration between the Scottish and UK governments. As McCollum explains:

The character of immigration to Scotland is distinctive, in terms of both the nature of immigration flows and social attitudes to immigration. Although no longer the case, Scotland has traditionally lost more people than it has gained through migration. Related to this, the foreign-born population of Scotland is lower than the UK level generally. However a modest rate of natural increase (births minus deaths) means that Scotland is dependent on migration for demographic stability and growth to a greater extent than the other constituent countries of the UK (2013: no page number)

By contrast the UK government, which also legislates on English social policy matters including housing, has taken a more negative stance, with popular public opinion also more hostile to immigration (Migration Observatory, 2013; McCollum, 2013). This may in part explain why political parties such as UKIP and the BNP enjoy greater electoral support in England than they do in Scotland.

\section{Criticisms of the Right to Rent Scheme}

The differences between the Immigration Acts of 2014 and 2016, although few in number with respect to renting, could potentially have a large impact upon a wide range of housing services across the UK. For the issue of residential tenancies, the Immigration Act 2016 adds to the previous penalty of a fine the possibility of a mandatory prison sentence (not exceeding five years) for breaching the terms of the right to rent regulations. It therefore makes breach of the scheme a criminal offence. It also extends the provisions of the Act to registered social landlords (RSLs) and, as with the 2014 Act can, at the behest of the Secretary of State, be enacted in Scotland. Furthermore, it extends the eviction rights of landlords allowing them to seize repossession of their property more promptly than before. Its most significant differences to the previous Act lie in the extension of the State's surveillance powers to banking and driving licence provision. In Scotland (as with other parts of the UK) these proposals have met with widespread criticism and, in some quarters, open condemnation. The Scottish Government (2015), the Scottish Refugee Council (2015a) and the Law Society of Scotland (2015) have all said that the Act's proposals will 
p. 119. The Immigration Act and the 'Right to Rent': exploring governing tensions within and beyond the state (Policy Commentary)

increase levels of homelessness, and discriminate against all migrants rather than reduce immigration. Social Justice Secretary Alex Neil MSP outlined significant concerns around the Act and criticised the UK government for rushing through legislation, which impacts on devolved areas like housing and justice:

I am disappointed to see the inhumane measures set out in the Immigration Bill and I am deeply concerned if approved, that they will encourage people to discriminate against this vulnerable group. The UK Government's approach, coinciding with its delayed response to the worst humanitarian crisis facing Europe since the Second World War, shows an unbelievable lack of compassion and understanding of people's basic rights. We will do all we can to stand against the proposals in the bill, which will leave people at risk of homelessness or destitution. We are committed to creating a fairer Scotland, where we provide protection, safety and security to those who need it most. Alex Neil Social Justice Secretary (Scottish Government, 2015: no page number)

The Scottish Refugee Council's (2015b) 'statement of concern', written in response to the Act (when it was at the Bill stage), was co-signed by Shelter, the Scottish Federation of Housing Associations, Scottish Association of Landlords, Chartered Institute of Housing (CIH Scotland), Royal College of GPs in Scotland, Migrant Voice and Migrant Rights Scotland. Collectively, these organisations have condemned the UK government's proposals on the grounds that a humanitarian and refugee crisis is not the time for more restrictive asylum and immigration legislation. One of their main objections centres on the fact that there is no evidence to suggest these measures will lead to less people entering the UK or indeed more people departing. More significantly they do, however, claim that there is no shortage of evidence that these measures will facilitate great suffering on already vulnerable people. This could, the co-signatories claim, place unprecedented pressures on councils and services as well as charity organisations. This is of course a prominent facet of the neoliberal turn, as States devolve their responsibilities for welfare, protection and care, relying on the voluntary and private sectors to carry this accountability. Shelter (2016) have voiced their concern that lack of rental opportunities and increased evictions will amplify pressure on groups like Shelter who will be hard pressed to assist them. One of the Scottish Refugee Council's (2015b) Statement of Concern's biggest fears is that the Act will provide a boon to organised crime, increasing the vulnerability to exploitation of individuals and families who have unmet accommodation needs. This could, they assert, lead to unconscious racial discrimination, as people who do not 'look British' are placed in a position of having to prove that they are, or that they are legally entitled to rent here (see also, Shelter, 2016). Landlords might not want to 'take any risks' and may opt to refuse to let to anyone who doesn't look 'British' in the first instance. Determinations may be made at the initial encounter stage.

There are also concerns about the 'right to rent' scheme being rolled out without any detailed discussion of the impacts in the pilot area (CIH Scotland, 2015; Law Society of Scotland, 2015; Shelter, 2016). The right to rent pilot was rolled out in the West Midlands, and specifically included Birmingham, Dudley, Sandwell, Walsall and Wolverhampton. It took place between $1^{\text {st }}$ December 2014 until 31 ${ }^{\text {st }}$ May 2015. Freedom of Information Act requests show that only seven notices to evict had been issued to landlords during the entire pilot period, leading to calls for more research to assess the effectiveness of the scheme (ClH Scotland, 2015; Law Society of Scotland, 2015; Shelter, 2016).

Another concern revolves around the issue of evictions (Scottish Government, 2015; CIH Scotland, 2015; Shelter Scotland, 2016). Housing is a devolved matter; 
p. 120. The Immigration Act and the 'Right to Rent': exploring governing tensions within and beyond the state (Policy Commentary)

therefore, separate legislation would be required to be put in place to change the processes for eviction in Scotland that were discussed in the previous section:

We believe it conflicts with the Scottish Government's objective to promote fairness and equality in Scottish housing policy and to increase security for the growing number of tenants in the private rented sector. The Scottish Parliament must be fully consulted before any moves to extend the proposed eviction measures to Scotland. Annie Mauger, Director $\mathrm{CIH}$ Scotland (CIH, 2015)

This separate legislation would have to reflect the content of the recently passed Private Housing (Tenancies) (Scotland) Act 2016. Shelter (2016) are correspondingly concerned that the 28 day notice period will not be sufficient for immigration officers to ascertain the tenant's immigration status, or allow the tenant to mobilize an appeal. They have urged MSPs to determine how this law will be rolled out in Scotland, arguing that the, "Scottish Parliament should be accorded legislative consent and the time to scrutinize the aspects of this Bill that relate to devolved powers" (Shelter Scotland, 2016: 4).

\section{Landlords: the new border agents in the UK's securitisation}

By according private landlords such a pivotal role in regulating and policing the border, the Immigration Act 2016 places tenants in a potentially vulnerable relationship with their landlord. Whilst the context of requiring landlords, including those in the private sector, to play a central role in delivering social policy objectives is not new (see for example, past legislation on Anti-Social Behaviour, and policy outcomes on local economic development and community cohesion), this legislation illuminates potential discriminatory aspects of UK government policy, as the workings of the current Act are premised on demonizing those who are undocumented within the UK. However, by extension this initially makes it difficult for all those who do not appear "British or Scottish" on first encounter to attain tenancy. The Immigration Act criminalizes all undocumented people, regardless of how long they have been here for, their efforts to comply with the UK system, how they arrived to the UK, whether they were trafficked here, and why they are here, for example, whether they are here to escape injustice elsewhere. It paints all undocumented people with the same brush of illegality first above all else. This Act therefore has the potential to heighten ethnic discrimination within the UK making an already volatile environment much more incendiary.

Etienne Balibar (2002) famously discussed the ubiquitous, vacillating and everywhere notion of the border, utilizing class as a major differentiator of how people experience and relate to the border. He argued that the border is no longer a traditional line on a map, or beginning at the sovereign territorial edge of the state. Borders are now becoming more commonplace, found in multiple venues and apparent at various scales, for him, and many others who study in this area, they become in various ways "things within the space of the political itself" (2002: 92). Furthermore, Balibar notes how physical borders and various other strategies of bordering control are used as "instruments of discrimination and triage" (2002: 82). Borders are material things of separation, but are furthermore internalized by individuals and both constitute and are constituted by peoples' identities; working differently on physical things than they do for human beings. Balibar utilizes the work of the psychoanalyst Andre Green to note that people can in essence be a border. It is this embodiment of the border that the Immigration Act relies on, drawing on landlords' notions of who is part of the territory and who is not. Leading them to make determinations by initially relying on who embodies the border for them. 
p. 121. The Immigration Act and the 'Right to Rent': exploring governing tensions within and beyond the state (Policy Commentary)

David Cameron in his speech on immigration in May 2015 stressed the efficacy of the Immigration Act and the right to rent legislation in particular. He noted that this legislation provided additional means by which "we can identify those who shouldn't be here" (2015: 1). Is the "we" he speaks of a shirking of responsibility from traditional State security and border protection agents, to all of those seen as legally within the State? We strongly believe that this is a neoliberal strategy, building on many other processes, such as the reconfiguration of the welfare state, and the increased reliance on non-state actors in the voluntary, private and community sectors to deliver social welfare goals (McKee, 2015). Using the opportunity to highlight the Conservative Party majority in Government, Cameron (2015: 2) again used the pronoun "we" to discuss the many ways in which the 'right to rent' legislation deals with the private rented housing sector, claiming that it is a multi-functional catch all piece of legislation. He declared that "we'll change the rules so landlords can evict illegal immigrants more quickly...we'll also crack down on the unscrupulous landlords who cram houses full of illegal migrants... we'll consult on cancelling tenancies automatically at the same point". As highlighted in the introductory section of this paper, such comments highlight the way in which debates about housing and immigration have become entangled.

Is the UK Government now expecting those legally in the state to pay the price for the failures of the institutional State functionaries to protect and police its own border? Foucault (2009) understood the law as a set of tactics, a directory of strategies that vitalize and invigorate the state. His later work on governmentality drew attention to the myriad of ways in which governing was now enacted beyond the state, with an emphasis on both the discursive problematization of particular types of 'subjects', as well as the concrete and actual practices of rule, which varied temporally and spatially (Foucault, 2003; McKee, 2009). The 'right to rent' legislation is a strong, contemporary example of the governing tensions within this neo-liberal project. It deputizes to landlords the discretionary and decision-making power to regulate and control a factor of their tenants' lives, allowing them to make state sanctioned decisions, even if that is with respect to political life and its attendant representation. This quasi decisionmaking power serves to activize and enliven the landlord's role as state agent and protector. Judith Butler (2006), when discussing Guantanamo and the US role in its maintenance, talked about not only the state of exception and the suspension of law, but also the functioning of governmentality and how its various tools act to energize and stimulate the workings of the state. The Immigration Act has a dual function both holding landlords to account and giving them a sense of some semblance of sovereign power, functioning within and through government legislation. Butler speaks historically about the rise of disciplinary power and the contemporary resurgence of sovereignty, which relies upon the mobilization of what she has termed "petty sovereigns"; this is exactly the way the right to rent legislation is functioning. Butler argued that these petty sovereigns were "mobilized by aims and tactics of power they do not inaugurate or fully control" (2006: 56). She goes on to argue that this type of power held by petty sovereigns is a "rogue power". This is particularly pertinent to what is happening with the 'right to rent' legislation. Decisions are being made by landlords with no real qualifications or training to prepare them. The State is augmenting its own power through the use of those landlords. These decision-makers become "part of the apparatus of governmentality" (Butler, 2006: 59).

The mentality around the 'right to rent' legislation acts to manage the relationship between landlord and tenant, and the relationship between the landlord and State, and indeed, the tenant and the State. The regulations involved maintain and bolster phenotypical difference within society, asking landlords to make determinations based on their understanding of who embodies the border for them. It also operates as a way to account for and register both the landlord and their would-be tenants. Using landlords as petty sovereigns raises the key question of legitimacy. What legitimacy do 
p. 122. The Immigration Act and the 'Right to Rent': exploring governing tensions within and beyond the state (Policy Commentary)

they have to act as part of, or on behalf of, the State, and what legitimacy does the State have to prosecute landlords who fail in their attempts to check their tenants' documentation, or is this just a further act by the State to promote ethnic discrimination among the populace. A recent appeal case puts the potential for landlord prosecution in cases of failure to verify immigration documentation in jeopardy. The airline company Ryanair was recently fined for transporting migrants with forged documentation. Upon appeal, the judge espoused that Ryanair staff should not be held accountable if passengers have forged passports, as they are not adequately trained in the ways and methods of detecting forgeries. The Residential Landlord's Association's policy director David Smith said: "This court ruling vindicates what we have been saying all along, that landlords cannot and should not be expected to act as border police or to detect forgeries that trained and experienced airline staff and immigration officers might miss" (RLA Landlord News Hub, 2016: no page number).

\section{Conclusion}

Looking forward, any future research agenda will need to meet the theoretical challenge of understanding why policies that are met with such widespread opposition, still manage to make it through the legislative process. It also needs to apply a more critical lens to the underlying agendas that apply to the actualisation of and compliance with any new laws, which have the potential to direct responsibility of state functions of surveillance, border work and detection to its citizens. As can be seen above, the opposition to the Immigration Act, like many of the current policies of the recent UK Conservative Government, have been met with widespread condemnation from the UN inspectorate (Rolnik, 2013), the UK judiciary (see Court of Appeal Decisions, 2016), the House of Lords ${ }^{1}$ and a whole raft of institutions and organisations, including the devolved governments of Scotland, Northern Ireland and Wales. We do accept that public attitudes may differ from those of 'officials' who, acting in an official capacity, have a different view of the issues that the general public does. That said, there is no evidence to suggest that the 'right to rent' is more popular with the Scottish public than it is with professionals, although this may be the case. This issue does require further exploration and at least some degree of empirical testing in order to fully understand.

In order to understand how these measures are directly impacting the private rented sector, the tenant and devolved Scottish policy, it is necessary to conduct an initial set of qualitative investigations, speaking directly to those affected by 'right to rent', as well as the agencies who represent their interests and who are mandated to speak on their behalf. This includes a broad range of organisations and people such as landlords, immigration advice centres and legal advocates, charities working with asylum seekers and immigrant groups, as well as those working in local authorities and in local government. Research of this nature has the potential to further our understanding of this Act's potential impact upon devolved areas of legal competence, as well as the impact upon landlords and welfare state providers and the communities they serve. Building on this it may also be pertinent to explore potential tensions between the accounts of key-actors (e.g. housing professionals), and the wider citizenry (e.g. general public). Research on welfare sanctions for examples highlights potential populist support for social policies that have been heavily criticised by experts. In addition, it is important to ask what other devolved powers can be circumvented by the UK Government, by linking an Act to non-devolved issues, such as it has done with immigration in this case. Ultimately, we also need to unveil the Government's role in furthering discrimination and unease within society, and examine how its policies create a smoke screen linked to the removal of "illegal" groups to maintain and propel suspicion of all those who are deemed different by the majority. 
p. 123. The Immigration Act and the 'Right to Rent': exploring governing tensions within and beyond the state (Policy Commentary)

\section{Notes}

1 Prime Minister David Cameron has threatened to reform the House of Lords after it defeated the Government's plan to scrap tax credits in 2015.

* Corresponding author: Dr Joe Crawford, Centre for Housing Research, Department of Geography and Sustainable Development, University of St Andrews, Irvine Building, North Street, St Andrews, Fife, KY16 9AL. Email: jc292@st-andrews.ac.uk

\section{References}

Abbasi, K., Patel, K. and Godlee, F. (2015) Europe's refugee crisis: an urgent call for moral leadership. BMJ, 351, h4833.

Albahari, M. (2015) Europe's refugee crisis. Anthropology Today, 31, 1-2.

Balibar, E. (2002) Politics and the Other Scene. London: Verso.

BBC News (2016) EU Referendum: vote leave in housing appeal to young. Available from: $\quad$ http://www.bbc.co.uk/news/uk-politics-eu-referendum-36431474 [Accessed: 2 June 2016]

Beatty, C., Foden, M., McCarthy, L. and Reeve, K. (2015) Benefit Sanctions and Homelessness: A Scoping Report. Available from: http://www4.shu.ac.uk $\angle$ research/cresr/sites/shu.ac.uk/files/homeless-experiences-welfareconditionality-benefit-sanctions.pdf

Butler, J. (2006) Precarious life: the powers of mourning and violence. London: Verso.

Cameron, D. (2015) PM Speech on Immigration 21 May 2015. London: Prime Minister's Office. Available from: https://www.gov.uk/government/speeches/pmspeech-on-immigration [Accessed: 29th May 2016]

Chartered Institute of Housing (2015) Immigration Bill Eviction Measures Should Not be Extended to Scotland. Available from: http://www.cih.org/newsarticle/display/vpathDCR/templatedata/cih/newsarticle/data/Immigration_Bill_eviction_measures_should_not_be_extended_to_S cotland [Accessed: 20 June 2016]

Conservativehome.com (2015) Let's not get carried away. The Conservatives only won over a quarter of all potential voters. Available from: http://www.conservativehome.com/highlights/2015/05/lets-not-get-carriedaway-the-conservatives-only-won-over-a-quarter-of-all-potential-voters.html [Accessed: 20 June 2016]

Court of Appeal Decisions (2016) [2016] EWCA Civ 29 Case Nos: C1/2014/2539 \& C1/2015/0502. Available from: http://www.bailii.org/ew/cases/EWCA /Civ/2016/29.html [Accessed: 20 June 2016]

Daily Mail (2016) Migrants Spark Housing Crisis: now EU tells Britain to build more homes as open borders send population soaring. Available from: http://www.dailymail.co.uk/news/article-3599970/Migrants-spark-housing-crisisEU-tells-Britain-build-homes-open-borders-send-population-soaring.html [Accessed: 8 June 2016]

Foucault, M. (2009) Security, territory, population: lectures at the Collège de France: 1977-78. Basingstoke: Palgrave Macmillan.

Foucault, M. (2003) Governmentality, In: P. Rabinow and N. Rose (eds) The Essential Foucault: selections from Essential Works of Foucault 1954-1984. London: The New Press (original 1978), pp. 229-245.

Her Majesty's Stationary Office (HMSO) (1987) Housing (Scotland) Act 1987. Available from: $\quad$ http://www.legislation.gov.uk/ukpga/1987/26/pdfs/ukpga 19870 $\underline{026 \text { en.pdf }}$ 
p. 124. The Immigration Act and the 'Right to Rent': exploring governing tensions within and beyond the state (Policy Commentary)

Her Majesty's Stationary Office (1995) Children (Scotland) Act 1995. Available from: http://www.legislation.gov.uk/ukpga/1995/36/section/25

Her Majesty's Stationary Office (2006) Housing (Scotland) Act 2006. Available from: http://www.legislation.gov.uk/asp/2006/1/section/13

Her Majesty's Stationary Office (2011) The Tenancy Deposit Schemes (Scotland) Regulations 2011. Available from: http://www.legislation.gov.uk/sdsi/2011/9780111011850/pdfs/sdsi 9780111 011850 en.pdf

Her Majesty's Stationary Office (2016) Private Housing (Tenancies) (Scotland) Act 2016. Available http://www.legislation.gov.uk/asp/2016/19/contents/enacted [Accessed: 6 June 2016]

Home Office (2016) Immigration Act 2016. Available from: https://www.gov.uk/government/collections/immigration-bill-2015-16 [Accessed: 6 June 2016]

Law Society of Scotland (2015) Immigration Bill: Second reading brief. Available from: https://www.lawscot.org.uk/media/644984/imm-immigration-Act-secondreading-briefing-paper-law-society-of-scotland.pdf

Manning, A., Battison, D., Dickens, R. and Wadsworth, J. (2014) Immigrants Access to Social Housing: perception and reality. Centrepiece Spring 2014. Available from: http://cep.Ise.ac.uk/pubs/download/cp420.pdf [Accessed: 6 June 2016]

McCollum, D. (2013) "Constitutional Change and Immigration in Scotland", guest blog for Centre on Constitutional Change. Available from: http://www.centreonconstitutionalchange.ac.uk/blog/constitutional-change-andimmigration-scotland [Accessed: 6 June 2016]

McKee, K., Muir, J. and Moore, T. (2016) Housing Policy in the UK: the importance of spatial nuance. Housing Studies (Online Early): http://www.tandfonline.com/doi/full/10.1080/02673037.2016.1181722

McKee, K. (2015) Community Anchor Housing Associations: illuminating the contested nature of neoliberal governing practices at the local scale. Environment and Planning C, 47, 1-16.

McKee, K. (2011) Sceptical, Disorderly and Paradoxical Subjects: problematising the 'will to empower' in social housing governance. Housing Theory and Society, 28, 1, 1-18.

McKee, K. (2009) Post-Foucauldian Governmentality: what does it offer critical social policy analysis? Critical Social Policy, 29, 3, 465-486.

Migration Observatory (2013) Immigration and Independence: public opinion on immigration in Scotland in the context of the Referendum Debate. Available from: http://www.migrationobservatory.ox.ac.uk/sites/files/migobs/Report\%20\%20immigration\%20and\%20independence_0.pdf [Accessed: 6 June 2016]

Robinson, D. (2010) New Immigrants and Migrants in Social Housing in Britain: discursive themes and lived realities. Policy and Politics, 38, 1, 57-77.

Robinson, D. (2006) Living Parallel Lives? Residential Segregation, Community Cohesion and Housing, In: H. Beider (ed.) Residence, Renewal and Community Empowerment: comparing approaches in the US and the UK. London: MacMillan.

Residential Landlords Association Landlord News Hub (2016) Court Judgement Could Impact Right to Rent. Available from: http://news.rla.org.uk/court-judgementcould-impact-right-to-rent/ [Accessed: 23 April 2016]

Rolnik, R. (2013) United Nations Report of the Special Rapporteur on adequate housing as a component of the right to an adequate standard of living, and on the right to non-discrimination in this context. Available from: http://www.ohchr.org/EN/Issues/Housing/Pages/Housinglndex.aspx 
p. 125. The Immigration Act and the 'Right to Rent': exploring governing tensions within and beyond the state (Policy Commentary)

Scottish Government (2015) Proposals will discriminate against migrants 17/09/2015 15:41. Available from: http://news.scotland.gov.uk/News/Proposals-willdiscriminate-against-migrants-1d3d.aspx

Scottish Refugee Council (2015a) Briefing for Second Reading of the Immigration Bill in House of Commons on 13 October 2015. Available from: http://www.scottishrefugeecouncil.org.uk/assets/0001/0207/Briefing_for_2nd_ Reading of the Immigration Bill - 131015.pdf

Scottish Refugee Council (2015b) Statement of concern on the impact of the Immigration Bill on Scotland's communities. Available from: http://www.scottishrefugeecouncil.org.uk/news and events/news/2259 serious concern_raised_over_immigration_bill_proposals [Accessed: 21 May 2016]

Shelter Scotland (2016) Shelter Scotland briefing for debate on Motion S4M-15116 Impact of the UK Immigration Bill on Scotland. Available from: http://scotland.shelter.org.uk/professional_resources/policy_library/policy_librar $\mathrm{y}$ folder/briefing for debate on motion s4m15116_impact_of_the_uk_immigration_bill_on_scotland [Accessed: 21 May 2016]

Stalker, A. (2007) Evictions in Scotland. Edinburgh: Avizandum.

Stewart, A. and Wright, S. (2014) Conditionality Briefing: Unemployed People. Available

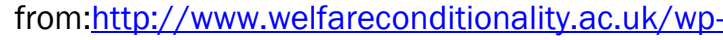
content/uploads/2014/09/Briefing_Unemployment_14.09.10_FINAL.pdf [Accessed: 21 May 2006]

Telegraph (2013) Half a Million Immigrants Given Social Housing in the Last Decade. Available from: $\quad$ http://www.telegraph.co.uk/news/uknews/immigration $\angle 10205963 /$ Half-a-million-immigrants-given-social-housing-in-the-lastdecade.html [Accessed: 6 June 2016]

UK Visas and Immigration and Home Office (2015) Immigration Bill: part 2 - access to services. London: UK Visas and Immigration and Home Office. Available from: https://www.gov.uk/government/publications/immigration-bill-part-2-access-toservices. [Accessed: 23 April 2016]

Vargas-Silva, C. (2015) Briefing: Migrants and Housing in the UK: experiences and impacts. Available from: http://www.migrationobservatory.ox.ac.uk/sites/files/ migobs/Briefing\%20-\%20Migrants\%20and\%20Housing\%20in\%20the\%20UK.pdf [Accessed: 6 June 2016] 